\title{
Measuring the effect of international financial reporting standards on quality of accounting performance and efficiency of investment decisions
}

\author{
Alaa Malo-Alain ${ }^{a^{*}}$, Mahfod Mobarak Aldoseri ${ }^{\mathrm{b}}$ and Magdy Abdul Hakim Melegy ${ }^{\mathrm{c}}$
}

${ }^{a}$ Al-Balqa Applied University, Jordan

${ }^{b}$ Prince Sattam Bin Abdulaziz University, Community College, Saudi Arabia ${ }^{c}$ Benha University, Faculty of Commerce, Egypt

\section{H R O N I C L E}

Article history:

Received: July 28, 2020

Received in revised format: July 302020

Accepted: September 6, 2020

Available online:

September 14, 2020

Keywords:

IFRS

Conservatism

Earning Management

Quality of Accounting

Performance

Cost of Capital

Efficiency of Investment decision

\section{A B S T R A C T}

The purpose of this study is to verify the impact of international financial reporting standards (IFRS) adoption on the quality of accounting performance and efficiency of investment decisions in the Saudi business environment as an emerging economy. In this study, content analysis approach is adopted for examining the annual reports of Saudi companies listed in Saudi stock exchange market during two periods: the pre-adoption of IFRS period during the year of 2016 and the post-adoption of IFRS period during the period 2017-2018. The study uses accounting information, accounting conservatism, earning management as alternative variables of accounting performance quality. In addition to accounting profit quality, liquidity and cost of capital are also used as alternative variables for the efficiency of investment decisions. The study finds that there was a positive impact of IFRS adoption on the quality of accounting performance, since it was positively related to both the qualitative characteristics of information and accounting conservatism, while it was negatively related to earning management. IFRS also improves the efficiency of investment decisions, as it was positively related to both profit quality and liquidity while it was negatively related to cost of capital.

\section{Introduction}

Several accounting studies have confirmed that the adoption of IFRS has contributed to improve the quality of information provided to different categories of users by providing relevant, understandable and highly reliable information (Defond, 2019), in addition to, making the accounting data of companies comparable with the data of other companies for different periods (Drobetz et al., 2019). Convergence with IFRS has become an imperative to promote global economic stability and integration, and it also encourages investors to invest outside their countries where investors are concerned that financial information is appropriate, reliable, timely and comparable (Lin et al., 2019; Bui et al., 2020). Therefore, the adoption of IFRS may improve the ability of companies to access external financing and enhance investor confidence in the capital market. The main objective of this research is to analyze the impact of mandatory adoption of IFRS on the quality of accounting performance and the efficiency of investment decisions of Saudi Public Shareholding Companies. In terms of research significance, this research presents a practical guide on the impact of adoption IFRS on the quality of accounting performance and the efficiency of investment decisions in Saudi business environment as one of the newly adopting emerging economies of IFRS. In addition, the

* Corresponding author

E-mail address: prof.maloain@bau.edu.jo (A. Malo-Alain) 
results of this study may provide useful information to the bodies regulating, organizing and responsible for the adoption and development of IFRS all over the economic sector in Saudi business environment. The main motivations of this research are that emerging markets need to keep pace with developed markets concerning to IFRS adoption to improve the quality of accounting information, where these markets suffer from increasing discrepancy in information, less compliance with laws, regulations and publications that regulate accounting profession. Furthermore, the research gap that requires further investigation to analyze and measure the feedback of adopting IFRS on the quality of accounting performance and efficiency of investment decisions. Based on above, the research problem can be identified by the following questions:

What is the impact of IFRS adoption on the quality of accounting performance?

What is the impact of IFRS adoption on the efficiency of investment decisions?

\section{IFRS and Accounting Conservatism}

Accounting literature presented different views that contributed to interpret the relationship between accounting conservatism and the quality of accounting information. The first point of view suggests that, there is a negative relationship between accounting conservatism and the quality of accounting performance, the justification for this opinion depends on the fact that, accounting conservatism policy results in a distortion of accounting information quality, as this policy leads to non-compliance with the impartiality of information, and the credibility of expression, which may adversely affect the appropriateness of accounting information when making comparisons. In this context, Gokmen (2013) pointed out that accounting policy restricts the information content of financial reports, thereby reducing its ability to predict the future. Cheng and Kung (2015) and Fuad et al. (2017) reported that the increase in the level of conservatism leads to formation of hidden reserves - by the value of the difference between the net assets under accounting conservatism policy and its value in the presence of less conservative accounting policy - which is used by the company's management to increase profits in future periods, especially in the light of the low growth rate of investments in those periods. The second view suggests that, there is a positive relationship between accounting conservatism and the quality of accounting performance. In this context, Hu et al. (2014) perceived that accounting conservatism contribute to improve the quality of information, and this is more pronounced in the weak legal protection countries. On the other side, Lawani et al. (2015) suggests that the adoption of accounting conservative practices in the light of high level of disclosure quality contributes to reduce the information asymmetry gap and reducing uncertainty about future cash flows. In this direction, the first test hypothesis predicts that:

$\mathrm{H}_{1}$ : There is a significant and positive correlation between the adoption of IFRS and accounting conservatism.

\subsection{IFRS and Earning management}

Agency Theory provides an analytical framework for understanding the impact of IFRS on managerial opportunistic behavior. This theory assumes that IFRS contributes to solve agency problems, reduce subjective judgments. This theory assumes that IFRS relate to disclosure transparency and increasing control over management behavior, which is reflected in the reduction of earning management practices. In this context, Beuren and Klann (2015) notes that switching to IFRS limits accounting earning management practices. Capkun et al. (2016) attempted to measure the effect of the transition from local accounting standards to IFRS and its impact on the level of earning management measured by income smoothing behavior. The study concluded that, there was an increment in the level of earning management practice (income smoothing) during the period of optional adopting of IFRS (pre-2005) compared to the mandatory adoption of IFRS (post-2005), and that was due to making adoption more flexible and responsive to the needs of management to use different accounting alternatives and practices, ultimately, practicing to a great extent personal judgment. In this direction, the second test hypothesis predicts that:

$\mathrm{H}_{2}$ : There is a significant and negative correlation between the adoption of IFRS and earning management practice.

\subsection{IFRS and characteristic of accounting information}

Some studies focused on the impact of IFRS on the informational content of financial reports. Leuz and Verrecchia (2000) perceived that companies adopting IFRS were distinguished by high quality financial reports comparing with companies adopting local standards in the German business environment. In the same context, Daske and Gebhardt, (2006) analyzed the impact of IFRS on the quality of annual corporate reports in three European countries - Austria, Switzerland and Germany - the study concluded that, there was an increasing rate in the disclosure quality during the adoption of IFRS. Similarly, Glaum et al., (2013) examined the changing level in the accuracy of analysts' expectations as a result of adopting IFRS, and whether that change was related to the disclosure quality. The study found that the disclosure in the notes attached in the financial statements and management reports was characterize of high quality for the companies adopting IFRS, in addition to, the improvement of disclosure quality resulted in an improvement in the accuracy of analysts' expectations. On the other side, Christensen et al., 
2013 provided an interesting discussion about the importance of IFRS adoption, as it contributes to improve transparency in the transactions and events, accounting principles and methods, estimates, judgments and personal estimates, and transparency of access to information. In this direction, the third test hypothesis predicts that:

$\mathrm{H}_{3}$ : There is a significant and positive correlation between the adoption of IFRS and the qualitative characteristics of accounting information.

\subsection{IFRS and the efficiency of investment decisions}

Several accounting literatures have addressed the impact of IFRS on the efficiency of capital markets by focusing on three main indicators: the first indicator is accounting profit quality, where accounting profit information is considered as one of the most important information for stakeholders, since it helps in assessing the firm performance, as well as evaluation of management performance. In this context, Ismail et al. (2013), found that the adoption of IFRS is associated with high profit quality, lower earning management and more appropriate value of accounting information, whereas, Horton et al. (2013) concluded that mandatory adoption of IFRS improves profitability, as the higher level of confidentiality, the lower level of accounting profit quality. The second indicator is market liquidity, Daske et al. (2008) found that adoption of IFRS resulted to an increase in market liquidity, but this was conditional to the existence of high-quality governance mechanisms with the obligation to apply IFRS. In the same context, Platikanova and Perramon (2012) found that the adoption of IFRS increased the comparability of financial reports, which is reflected on the informative content of these reports, in turn, increased the volume of trading in the market. The third indicator is the cost of capital, in this context, Castillo-Merino et al. (2014) found that the adoption of IFRS resulted to a significant reduction in the cost of capital. An extension of that, Silva and Nardi (2017) found that the adoption of IFRS leads to increase transparency, reduce cost of capital and ultimately, improve quality of profits. In this direction, the fourth test hypothesis predicts that:

\section{$\mathrm{H}_{4}$ : There is a positive and significant correlation between the adoption of IFRS and the efficiency of investment decisions.}

\section{Research methodology}

The study is based on the analysis of financial reports of joint stock companies registered in the Saudi stock exchange market during the period from 2016 to 2018 . The year 2016 includes companies before the adoption of IFRS, while the period from 2017 to 2018 includes companies after the adoption of IFRS, the study sample consisted of 80 companies, therefore, the total views of 240 company-year during the study period is considered. To measure the impact of IFRS adoption on the quality of accounting performance we considered the following

$$
\mathrm{QAF}=\beta_{0}+\beta_{1} \mathrm{IFRS}+\beta_{2} \mathrm{FSIZE}+\beta_{3} \mathrm{AUDT}-\beta_{4} \mathrm{LEV}-\beta_{5} \mathrm{CORG}+\beta_{6} \mathrm{PRO}+\varepsilon
$$

where

QAF: Quality of accounting performance is expressed by the characteristics of accounting information, accounting conservatism and earning management.

FSIZE: Company size

AUDT: Size of audit office

LEV: Degree of leverage

CORG: Governance mechanisms

PRO: Profitability.

To measure the impact of IFRS adoption on the efficiency of investment decisions, we have

$$
\mathrm{INE}=\beta_{0}+\beta_{1} \mathrm{IFRS}+\beta_{2} \mathrm{FSIZE}+\beta_{3} \mathrm{AUDT}-\beta_{4} \mathrm{LEV}+\beta_{5} \mathrm{CORG}+\beta_{6} \mathrm{PRO}+\varepsilon
$$

whereas: INE denotes to the efficiency of investment decisions, it is measured by liquidity, cost of capital and quality of profits.

\section{The results}

Table 1 shows the impact of IFRS on the efficiency of capital market, descriptive statistics depicts that the highest value of nondiscretionary accruals during the study period $=4.82$, while the lowest value $=0.084$, while the average liquidity $=46.2 \%$ and the average cost of capital $=0.263$. As far as the impact of IFRS on quality of accounting performance, Table 1 depicts the overall average quality of the qualitative characteristics of accounting information (relevance, reliability, understandability, comparability, consistency, and timeliness) $=37.229$ with SD 6.047. However, the average accounting conservatism was 4.217 . The descriptive statistics indicate that the study sample is oriented towards the practice of earning management either with the 
attitude to increase or decrease income, where the highest average of accounting profit $=637412$ and the lowest value $=-48123$. Regarding the controlling variables, the average size of the company is 11.52 , while the average leverage is 4.782 with a SD of 1.037. Table 1 shows also that the quality of governance $=4.826$. In addition, the average profitability during the study period was $31.4 \%$. Pertaining to dummy variables, Table 1 shows the number of companies that were complied with the adoption of IFRS during the study period reached 160 company with an average rate $(66.67 \%)$ compared to 80 company with an average rate $(33.33 \%)$ during the period of Pre-IFRS adoption. With regard to the number of companies that had been audited by both major and national auditing offices, the statistical descriptive analysis reveals that 140 company with an average rate (58.33\%) were audited by major auditing offices compared to 100 company with an average rate (41.67\%) were audited by national auditing offices.

Table 1

Descriptive Statistics of Study Variables

\begin{tabular}{|c|c|c|c|c|}
\hline Variable & Minimum & Maximum & Mean & Standard Deviation \\
\hline \multicolumn{5}{|l|}{ Part: 1: Continuous Variables } \\
\hline EQ & 0.084 & 4.82 & 0.321 & 0.453 \\
\hline ML & 0.315 & 0.461 & 0.462 & 0.03 \\
\hline WACC & 0.045 & 0.385 & 0.263 & 0.08 \\
\hline QC & 0.358 & 48.23 & 37.229 & 6.047 \\
\hline TRANS & 0.531 & 62.14 & 54.10 & 13.16 \\
\hline $\mathrm{CON}$ & 3.14 & 4.23 & 4.217 & 0.283 \\
\hline AEM & -48123 & 637412 & 371258 & 287523 \\
\hline FSIZE & 10.17 & 12.24 & 11.52 & 0.514 \\
\hline LEV & 2.31 & 6.25 & 4.782 & 1.037 \\
\hline CORG & 4 & 6 & 4.826 & 0.557 \\
\hline PRO & 0.215 & 0.481 & 0.314 & 0.051 \\
\hline 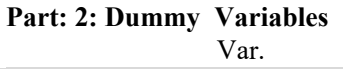 & & & & 1 \\
\hline IFRS & 80 & $33.33 \%$ & 160 & $66.67 \%$ \\
\hline AUDT & 100 & $41.67 \%$ & 140 & $58.33 \%$ \\
\hline
\end{tabular}

Table 2

Pearson Correlation Matrix

\begin{tabular}{|c|c|c|c|c|c|c|c|c|c|c|c|c|c|c|}
\hline & & 全 & O & $\dot{\Sigma}$ & \begin{tabular}{l}
0 \\
\multirow{3}{*}{} \\
3
\end{tabular} & $\mathscr{O}$ & 兄 & రె & $\sum_{i=1}$ & $\begin{array}{l}\text { II } \\
\text { I } \\
\text { I }\end{array}$ & 穴 & 省 & $\begin{array}{l}0 \\
0 \\
0\end{array}$ & $\frac{0}{a}$ \\
\hline IFRS & $\begin{array}{c}\text { Corr } \\
\text { Sig }\end{array}$ & 1.000 & & & & & & & & & & & & \\
\hline EQ & $\begin{array}{l}\text { Corr } \\
\text { Sig }\end{array}$ & $\begin{array}{c}.815^{* *} \\
.000\end{array}$ & 1.000 & & & & & & & & & & & \\
\hline ML & $\begin{array}{c}\text { Corr } \\
\text { Sig }\end{array}$ & $\begin{array}{c}.716^{* *} \\
.000\end{array}$ & $\begin{array}{c}-.652^{* *} \\
.000\end{array}$ & 1.000 & & & & & & & & & & \\
\hline WACC & $\begin{array}{c}\text { Corr } \\
\text { Sig }\end{array}$ & $\begin{array}{c}-.715^{* *} \\
.000\end{array}$ & $\begin{array}{c}.652 * * \\
.000\end{array}$ & $\begin{array}{c}-.652^{* *} \\
.000\end{array}$ & 1.000 & & & & & & & & & \\
\hline QC & $\begin{array}{c}\text { Corr } \\
\text { Sig }\end{array}$ & $\begin{array}{c}.673^{* *} \\
.000\end{array}$ & $\begin{array}{c}-.612^{* *} \\
.000\end{array}$ & $\begin{array}{c}.682^{* *} \\
.000\end{array}$ & $\begin{array}{c}-.586^{* *} \\
.000\end{array}$ & 1.000 & & & & & & & & \\
\hline TRANS & $\begin{array}{c}\text { Corr } \\
\text { Sig }\end{array}$ & $\begin{array}{c}.325^{* *} \\
.000\end{array}$ & $\begin{array}{c}-.361 * * \\
.000\end{array}$ & $\begin{array}{c}.472^{* *} \\
.000\end{array}$ & $\begin{array}{c}-.241^{* *} \\
.000\end{array}$ & $\begin{array}{c}.4542 * * \\
.000\end{array}$ & 1.000 & & & & & & & \\
\hline $\mathrm{CON}$ & $\begin{array}{c}\text { Corr } \\
\text { Sig }\end{array}$ & $\begin{array}{c}.761 * * \\
.000\end{array}$ & $\begin{array}{c}-.712^{* *} \\
.000\end{array}$ & $\begin{array}{c}.725^{* * *} \\
.000\end{array}$ & $\begin{array}{c}-.726^{* * *} \\
.000\end{array}$ & $\begin{array}{c}.723 * * \\
.000\end{array}$ & $\begin{array}{c}.342 * * \\
.000\end{array}$ & 1.000 & & & & & & \\
\hline AEM & $\begin{array}{c}\text { Corr } \\
\text { Sig }\end{array}$ & $\begin{array}{c}-.723 * * \\
.000\end{array}$ & $\begin{array}{c}.714 * * \\
.000\end{array}$ & $\begin{array}{c}-.712 * * \\
.000\end{array}$ & $\begin{array}{c}.734^{* * *} \\
.000\end{array}$ & $\begin{array}{c}-.616^{* *} \\
.000\end{array}$ & $\begin{array}{c}-.312 * * \\
.000\end{array}$ & $\begin{array}{c}-.723 * * \\
.000\end{array}$ & 1.000 & & & & & \\
\hline FSIZE & $\begin{array}{l}\text { Corr } \\
\text { Sig }\end{array}$ & $\begin{array}{c}.762 * * \\
.000\end{array}$ & $\begin{array}{c}-.712^{* *} \\
.000\end{array}$ & $\begin{array}{c}.761^{* *} \\
.000\end{array}$ & $\begin{array}{c}-.713^{* *} \\
.000\end{array}$ & $\begin{array}{c}.712^{* *} \\
.000\end{array}$ & $\begin{array}{c}.416^{* *} \\
.000\end{array}$ & $\begin{array}{c}.735^{* *} \\
.000\end{array}$ & $\begin{array}{c}-.754 * * \\
.000\end{array}$ & 1.000 & & & & \\
\hline AUDT & $\begin{array}{c}\text { Corr } \\
\text { Sig }\end{array}$ & $\begin{array}{c}.635^{* *} \\
.000\end{array}$ & $\begin{array}{c}-.618^{* *} \\
.000\end{array}$ & $\begin{array}{c}.628^{* *} \\
.000\end{array}$ & $\begin{array}{c}-.521^{* *} \\
.000\end{array}$ & $\begin{array}{c}.621^{* *} \\
.000\end{array}$ & $\begin{array}{c}.328^{* *} \\
.000\end{array}$ & $\begin{array}{c}.712^{* *} \\
.000\end{array}$ & $\begin{array}{c}-.623 * * \\
.000\end{array}$ & $\begin{array}{c}.649^{* *} \\
.000\end{array}$ & 1.000 & & & \\
\hline LEV & $\begin{array}{c}\text { Corr } \\
\text { Sig }\end{array}$ & $\begin{array}{c}-.723 * * \\
.000\end{array}$ & $\begin{array}{c}.741^{* *} \\
.000\end{array}$ & $\begin{array}{c}-.645^{* *} \\
.000\end{array}$ & $\begin{array}{c}.742^{* *} \\
.000\end{array}$ & $\begin{array}{c}-.651^{* *} \\
.000\end{array}$ & $\begin{array}{c}-.283^{* *} \\
.000\end{array}$ & $\begin{array}{c}-.725^{* *} \\
.000\end{array}$ & $\begin{array}{c}.728^{* *} \\
.000\end{array}$ & $\begin{array}{c}-.762^{* *} \\
.000\end{array}$ & $\begin{array}{c}-.613 * * \\
.000\end{array}$ & 1.000 & & \\
\hline CORG & $\begin{array}{c}\text { Corr } \\
\text { Sig }\end{array}$ & $\begin{array}{c}.613^{* *} \\
.000\end{array}$ & $\begin{array}{c}-.613^{* *} \\
.000\end{array}$ & $\begin{array}{c}.686^{* *} \\
.000\end{array}$ & $\begin{array}{c}-.581^{* *} \\
.000\end{array}$ & $\begin{array}{c}.523^{* *} \\
.000\end{array}$ & $\begin{array}{c}.321^{* *} \\
.000\end{array}$ & $\begin{array}{c}.624 * * \\
.000\end{array}$ & $\begin{array}{c}-.674 * * \\
.000\end{array}$ & $\begin{array}{c}.632^{* *} \\
.000\end{array}$ & $\begin{array}{c}.536^{* *} \\
.000\end{array}$ & $\begin{array}{c}-.523 * * \\
.000\end{array}$ & 1.000 & \\
\hline PRO & $\begin{array}{c}\text { Corr } \\
\text { Sig }\end{array}$ & $\begin{array}{c}.612^{* *} \\
.000\end{array}$ & $\begin{array}{c}-.715^{* *} \\
.000\end{array}$ & $\begin{array}{c}.652^{* *} \\
.000\end{array}$ & $\begin{array}{c}-.523^{* *} \\
.000\end{array}$ & $\begin{array}{c}.632^{* *} \\
.000\end{array}$ & $\begin{array}{c}.432 * * \\
.000\end{array}$ & $\begin{array}{c}.652^{* *} \\
.000\end{array}$ & $\begin{array}{c}-.583^{* *} \\
.000\end{array}$ & $\begin{array}{c}.628 * * \\
.000\end{array}$ & $\begin{array}{c}.627^{* *} \\
.000\end{array}$ & $\begin{array}{c}-.523^{* *} \\
.000\end{array}$ & $\begin{array}{c}.523^{* *} \\
.000\end{array}$ & 1.000 \\
\hline
\end{tabular}

(**) denotes to a statistically significant relationship at the level of 0.01 or less between the two variables

(*) denotes to a statistically significant relationship at the level of 0.05 or less between the two variables. 
Pearson correlation coefficient was used to determine the strength and direction of the relationship between IFRS and quality of accounting performance, and the efficiency of investment decisions. Table 2 shows the correlation matrix of the study variables. While we measure the correlation relationship between IFRS and capital market efficiency indicators, the results in Table 2 show that there was a positive correlation between IFRS and both profit quality and market liquidity, as the coefficient correlation registered 0.815 and 0.716 respectively for profit quality and market liquidity at a significance level 0.05 . whereas, there was a negative relationship between IFRS and cost of capital, as the correlation coefficient was negative -0.715 at a significance level of 0.05 . Concerning the relationship between IFRS and the quality of accounting performance, the results show a positive correlation between the adoption of IFRS and each of the qualitative characteristics of accounting information, transparency and accounting conservatism, where the value of coefficient correlation was positive for each indicator. Furthermore, there was a negative correlation between IFRS adoption and earning management at a significance level of 0.05 . Regarding the correlation between IFRS and capital market efficiency indicators, Table 2 reaveals that there was a positive correlation between IFRS and both profit quality and market liquidity, as the the coefficient correlation for profit quality and liquidity registered $0.815,0.716$ respectively at a critical value of less than equal 0.05 . In the context, the correlation between IFRS and cost of capital was negative, as the correlation coefficient $=-0.715 \mathrm{Sig}$. $=0.05$. Concerning to the relationship between IFRS and the quality of accounting performance indicators, the results of Table 2 show that there was a positive correlation between the adoption of IFRS and each of the qualitative characteristics of accounting information, and accounting conservatizm, as the correlation coefficient was positive for each indicator, whereas the correlation between IFRS and earning management was negative when the level of significance is five percent.

\subsection{Relationship between the adoption of IFRS and the quality of accounting performance}

Table 3 reveals the Adjust $\mathrm{R}^{2}$ for the qualitative characteristics of accounting information, accounting conservatism, and earning management $=0.624,0.586,0.715$ respectively, which reflects high explanatory value of regression model. Pertaining to the overall significance for regression model used, it can be identified by ANOVA that the calculated $F$ is statistically significant. Table 3 shows that IFRS had a significant effect on both the qualitative characteristics of accounting information and the accounting conservatism, where the regression coefficient $(\beta)$ was positive, Sig $=0.023$ for qualitative characteristics of accounting information, whereas for accounting conservatism, Sig $=0.00$. Regression analysis show that IFRS had a significant effect on earning management where regression coefficient $(\beta)$ was negative, $\mathrm{Sig}=0.024$. Indeed, this result was consistent with Huifa et al. (2010) and Ebaid (2016). From the results of regression analysis, we can conclude that there was a significant and positive correlation between the adoption of IFRS and accounting conservatism. There is a significant and negative correlation between the adoption of IFRS and earning management practice, there is a significant and positive correlation between the adoption of IFRS and the qualitative characteristics of accounting information.

\section{Table 3}

Model Summary for the relationship between the adoption of IFRS and the quality of accounting performance

\begin{tabular}{|c|c|c|c|c|c|c|c|c|c|c|c|c|}
\hline \multirow{3}{*}{$\begin{array}{l}\text { Dep.Var } \\
\text { Indep.Var }\end{array}$} & \multicolumn{4}{|c|}{$\mathrm{QC}_{\mathrm{t}}$} & \multicolumn{4}{|c|}{$\mathrm{CON}$} & \multicolumn{4}{|c|}{ AEM } \\
\hline & \multicolumn{2}{|c|}{$\begin{array}{l}\text { Unstandardized } \\
\text { Coefficients }\end{array}$} & \multirow[b]{2}{*}{$\mathrm{T}$} & \multirow[b]{2}{*}{ Sig. } & \multicolumn{2}{|c|}{$\begin{array}{l}\text { Unstandardized } \\
\text { Coefficients }\end{array}$} & \multirow[b]{2}{*}{$\mathrm{T}$} & \multirow[b]{2}{*}{ Sig. } & \multicolumn{2}{|c|}{$\begin{array}{l}\text { Unstandardized } \\
\text { Coefficients }\end{array}$} & \multirow[b]{2}{*}{$\mathrm{T}$} & \multirow[b]{2}{*}{ Sig. } \\
\hline & B & $\begin{array}{l}\text { Std. } \\
\text { Error }\end{array}$ & & & B & $\begin{array}{c}\text { Std. } \\
\text { Error }\end{array}$ & & & B & Std. Error & & \\
\hline (Constant) & 13.421 & 2.35 & $4.782 * *$ & .000 & -.236 & .263 & -.328 & .030 & 0.432 & 0.052 & $6.321^{* *}$ & 0.000 \\
\hline IFRS & 4.157 & 2.124 & $3.321 *$ & .023 & 2.384 & .741 & $12.13 * *$ & .000 & -0.027 & 0.017 & $-3.234 *$ & 0.024 \\
\hline FSIZE & 2.324 & .301 & $5.328 * *$ & .000 & .072 & .035 & $3.02 *$ & .023 & -0.085 & 0.023 & $-7.274 * *$ & 0.001 \\
\hline AUDT & 3.182 & .721 & $4.261 * *$ & .004 & .935 & .052 & $5.32 * *$ & .001 & -0.036 & 0.045 & $-4.012 * *$ & 0.003 \\
\hline LEV & -.720 & .362 & $-3.324 * *$ & .002 & -.081 & .013 & $-3.17 * *$ & .004 & 0.098 & 0.036 & $5.174 * *$ & 0.004 \\
\hline CORG & -.238 & .091 & $-3.186^{*}$ & .013 & .235 & .054 & $3.106^{*}$ & .021 & -0.014 & 0.027 & $-4.03 * *$ & 0.007 \\
\hline \multirow[t]{6}{*}{ PRO } & 20.234 & 4.25 & $6.421 * *$ & .000 & 2.712 & .279 & $2.421 * *$ & .000 & -0.362 & 0.027 & $-4.28 * *$ & 0.003 \\
\hline & \multicolumn{4}{|c|}{$R=.692$} & \multicolumn{4}{|c|}{$R=.673$} & \multicolumn{4}{|c|}{$R=.764$} \\
\hline & \multicolumn{4}{|c|}{$R^{2}=.631$} & \multicolumn{4}{|c|}{$R^{2}=.610$} & \multicolumn{4}{|c|}{$R^{2}=.732$} \\
\hline & \multicolumn{4}{|c|}{$\operatorname{Adj} R^{2}=.624$} & \multicolumn{4}{|c|}{$\operatorname{Adj} R^{2}=.586$} & \multicolumn{4}{|c|}{$\operatorname{Adj} R^{2}=.715$} \\
\hline & \multicolumn{4}{|c|}{$(\mathrm{F})$ value ANOVA $=230.174$} & \multicolumn{4}{|c|}{$(\mathrm{F})$ value $\mathrm{ANOVA}=237.372$} & \multicolumn{4}{|c|}{$(\mathrm{F})$ value ANOVA $=312.581$} \\
\hline & \multicolumn{4}{|c|}{$\mathrm{Sig}=.000$} & \multicolumn{4}{|c|}{$\mathrm{Sig}=.000$} & \multicolumn{4}{|c|}{ Sig $=.000$} \\
\hline
\end{tabular}

\subsection{Relationship between the adoption of IFRS and the efficiency of investment decisions}

The effect of IFRS on the efficiency of investment decisions was measured. The second hypothesis was divided into three subhypotheses, and the researcher relied on multiple regression analysis. Table 4 shows the impact of IFRS on the quality of accounting profits and liquidity as an indicators of investment decisions efficiency. Table 4 reveals the Adjust $\mathrm{R}^{2}$ for quality of accounting profit, market liquidity, and cost of capital as $0.534,0.512,0.601$ respectively, which reflect high explanatory value of regression model. Pertaining to the overall significance for regression model used, it can be identified by ANOVA that the calculated $\mathrm{F}$ for quality of accounting profits $=285.361$, whereas, for market liquidity $=253.725$, and for cost of capital $=$ 
263.172 at a significance level 0.000 , which is further indicates high significance of the model used. Regression analysis in table 4 shows that IFRS had a significant effect on both accounting profitability and market liquidity, where the regression coefficient $(\beta)$ was positive and $\mathrm{Sig}=0.000$ which is less than the critical value 0.05 proofing that "there is a positive and significant correlation between the adoption of IFRS and the quality of accounting profits and liquidity in the Saudi Stock Exchange." As a matter of fact, this result was consistent with both Silva and Nardi (2017), Ombati and Shukla (2018), Gao and Sidhu (2018), where they confirmed that IFRS leads to reduce the value of nondiscretionary accruals, ultimately, require more comprehensive disclosures, and thus, positively affects the quality of declared profits. Moreover, increasing the disclosure level may lead to discovering earning management practices. Regression analysis also show that IFRS had a significant effect on cost of capital, where the regression coefficient $(\beta)$ was negative and $\operatorname{Sig}=0.008$ which is less than the critical value 0.05 , and proves that there was a negative and significant correlation between the adoption of IFRS and low cost of capital in the Saudi stock market. Indeed, this result was consistent with Horton et al. (2013), as they concluded that IFRS applications limit earning management practices, and undoubtedly contributes to reduce information asymmetry more than local standards. This proves the validity of the fourth hypothesis that, there is a positive and significant correlation between the adoption of IFRS and the efficiency of investment decisions.

\section{Table 4}

Model Summary for the relationship between the adoption of IFRS and the efficiency of investment decisions

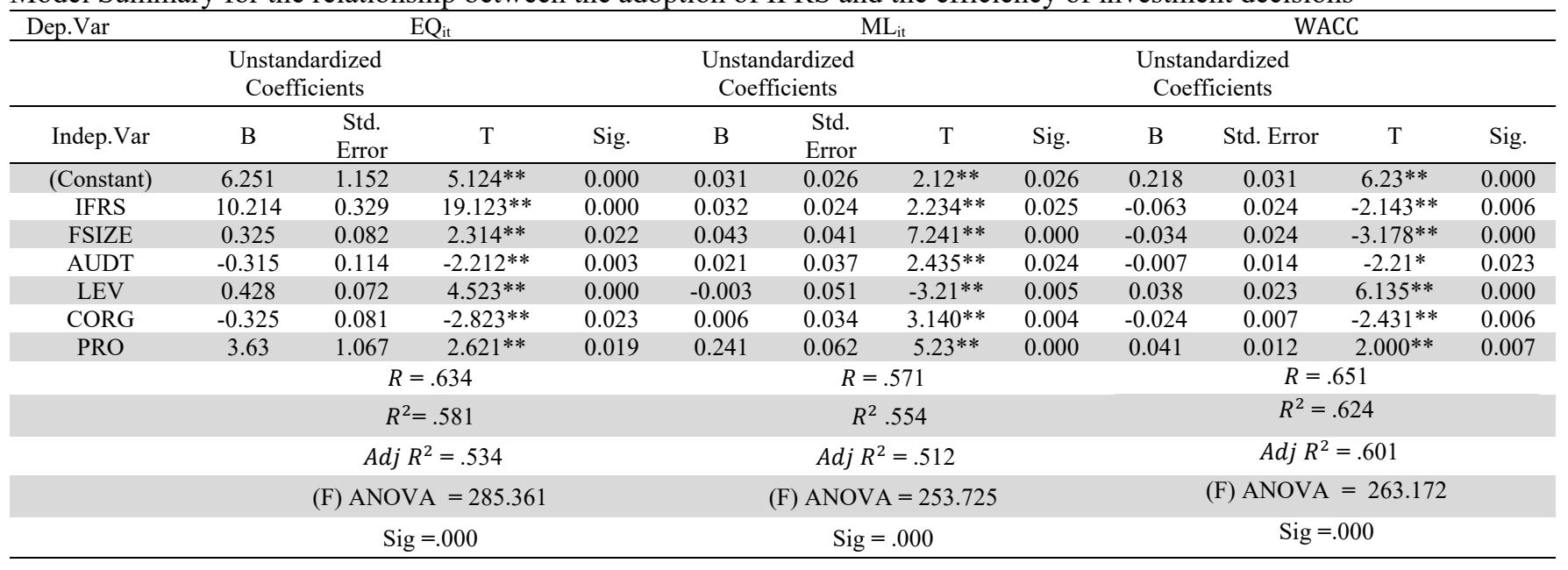

\section{Conclusion}

This study aimed to measure the impact of adoption IFRS on the quality of accounting performance and the efficiency of investment decisions for Saudi joint stock companies. Our study concluded that there was a positive impact of IFRS on the quality of accounting performance, and it leads to improve the qualitative characteristics of accounting information, such as appropriateness, representation, comparability, understandability, and timeliness. Furthermore, IFRS may increase the level of conservatism, and reduce the earning management practices, which is due to its high quality compared with local accounting standards. On the other hand, IFRS affects the efficiency of investment decisions in the Saudi business environment, since its positively increase in the quality of accounting profits, increasing the level of liquidity in the Saudi market, in addition to reducing low cost of capital, which affects the investors decisions. The study recommends that the IFRS should be continuously reviewed in the light of recent developments in order to fill up the gaps in some standards that might be exploited by the managements to undertake some opportunistic practices to achieve its own interests. Therefore, capital market authority (CMA) should take certain measures to monitor the adoption of IFRS by Saudi companies, in addition to, the importance of spreading awareness of IFRS among Accountants and Auditors through organization training courses about the most important amendments in IFRS, ultimately, developing the curriculums of Saudi universities. The results obtained of this study should be dealt with in the light of some limitations i.e. small sample size, excluding certain financial sectors (banks, insurance companies), as well as the study period. Furthermore, our study was limited to examine the impact of IFRS on the efficiency of investment decisions through some variables such as the quality of accounting profits, liquidity, and cost of capital. The study opens up prospects for future research and studies to highlight the relationship between the application of IFRS and social responsibility, Tax evasion, as well as the impact of IFRS on determining auditing fees and quality. 
Beuren, I. M., \& Klann, R. C. (2015). Effects of the convergence to international financial reporting standards in earnings management. International Journal of Finance and Accounting, 4(1), 8-20.

Bui, N., Le, O., \& Dao, H. (2020). Roadmap for the implementation of IFRS in Vietnam: Benefits and challenges. Accounting, 6(4), 533-552.

Capkun, V., Collins, D., \& Jeanjean, T. (2016). The effect of IAS/IFRS adoption on earnings management (smoothing): A closer look at competing explanations. Journal of Accounting and Public Policy, 35(4), 352-394.

Castillo-Merino, D., Menéndez-Plans, C., \& Orgaz-Guerrero, N. (2014). Mandatory IFRS adoption and the cost of Equity Capital. Evidence from Spanish Firms. Intangible Capital, 10(3), 562-583.

Cheng, C. L., \& Kung, F. H. (2016). The effects of mandatory corporate social responsibility policy on accounting conservatism. Review of Accounting and Finance, 15(10).

Christensen, H. B., Hail, L., \& Leuz, C. (2013). Mandatory IFRS reporting and changes in enforcement. Journal of Accounting and Economics, 56(2-3), 147-177.

Daske, H., \& Gebhardt, G. (2006). International financial reporting standards and experts' perceptions of disclosure quality. Abacus, 42(3-4), 461-498.

Daske, H., Hail, L., Leuz, C., \& Verdi, R. (2008). Mandatory IFRS reporting around the world: Early evidence on the economic consequences. Journal of Accounting Research, 46(5), 1085-1142.

DeFond, M., Gao, X., Li, O. Z., \& Xia, L. (2019). IFRS adoption in China and foreign institutional investments. China Journal of Accounting Research, 12(1), 1-32.

Drobetz, W., Janzen, M., \& Meier, I. (2019). Investment and financing decisions of private and public firms. Journal of Business Finance \& Accounting, 46(1-2), 225-262.

Ebaid, I. (2010). International accounting standards and accounting quality in code-law countries: The case of Egypt. Journal of Financial Regulation and Compliance. 24(1), 41-59.

Fuad, I., Januarti, \& Fahlevi, A. (2017). How mandatory IFRS covergence and conservatism determine the value relevance of accounting information: Empirical from Indonesia. Journal of Accounting, Finance and Auditing Studies, 3(3).

Gao, R., \& Sidhu, B. K. (2018). The impact of mandatory international financial reporting standards adoption on investment efficiency: Standards, enforcement, and reporting incentives. Abacus, 54(3), 277-318.

Glaum, M., Baetge, J., Grothe, A., \& Oberdörster, T. (2013). Introduction of international accounting standards, disclosure quality and accuracy of analysts' earnings forecasts. European Accounting Review, 22(1).

Gokmen, M.K. (2013). An empirical study on conditional conservatism and value relevance of earnings. International Journal of Social Science, 6(2).

Horton, J., Serafeim, G., \& Serafeim, I. (2013). Does mandatory IFRS adoption improve the information environment?. Contemporary Accounting Research, 30(1), 342-388.

$\mathrm{Hu}$, J., Li, A. Y., \& Zhang, F. F. (2014). Does accounting conservatism improve the corporate information environment?. Journal of international accounting, Auditing and Taxation, 23(1), 32-43.

Chen, H., Tang, Q., Jiang, Y., \& Lin, Z. (2010). The role of international financial reporting standards in accounting quality: Evidence from the European Union. Journal of International Financial Management \& Accounting, 21(3), $220-278$.

Ismail, W. A. W., Kamarudin, K. A., van Zijl, T., \& Dunstan, K. (2013). Earnings quality and the adoption of IFRS-based accounting standards. Asian Review of Accounting, 21(1).

Leuz, C., \& Verrecchia, R. E. (2000). The economic consequences of increased disclosure. Journal of Accounting Research, 38, 91-124.

Lawani, I. R., Umanhonlen, O. F., \& Okolie, R. O. (2015). Conservatism and value relevance of accounting information in quoted firms in Nigeria. International journal of finance and accounting, 4(1), 21-39.

Lin, S., Riccardi, W. N., Wang, C., Hopkins, P. E., \& Kabureck, G. (2019). Relative effects of IFRS adoption and IFRS convergence on financial statement comparability. Contemporary Accounting Research, 36(2), 588-628.

Ombati, R., \& Shukla, A. (2018). Analyzing the problems with the current adoption of IFRS in the companies among India, China, Germany, Russia and Kenya. Accounting, 4(1), 29-40.

Platikanova, P., \& Perramon, J. (2012). Economic consequences of the first-time IFRS introduction in Europe. Spanish Journal of Finance and Accounting/Revista Española de Financiación y Contabilidad, 41(156), 497-519.

da Silva, R. L. M., \& Nardi, P. C. C. (2017). Full adoption of IFRSs in Brazil: Earnings quality and the cost of equity capital. Research in International Business and Finance, 42(1), 1057-1073. 
(C) 2020 by the authors; licensee Growing Science, Canada. This is an open access article distributed under the terms and conditions of the Creative Commons Attribution (CC-BY) license (http://creativecommons.org/licenses/by/4.0/). 